\title{
Composition, Repellent, and Insecticidal Activities of Two South American Plants against the Stored Grain Pests Tribolium castaneum and Tribolium confusum (Coleoptera: Tenebrionidae)
}

\author{
Verónica Benzi, ${ }^{1,2}$ Natalia Stefanazzi, ${ }^{1}$ Ana Paula Murray, ${ }^{3}$ \\ Jorge O. Werdin González, ${ }^{2,3}$ and Adriana Ferrero ${ }^{1}$ \\ ${ }^{1}$ Laboratorio de Zoología de Invertebrados II, Departamento de Biología, Bioquímica y Farmacia, San Juan 670, \\ Universidad Nacional del Sur, B8000CPB Bahía Blanca, Argentina \\ ${ }^{2}$ Consejo Nacional de Investigaciones Científicas y Técnicas (CONICET), Avenida Rivadavia 1917, \\ C1033AAJ Ciudad Autónoma de Buenos Aires, Argentina \\ ${ }^{3}$ Instituto de Química del Sur (INQUISUR), Avenida Alem 1253, Universidad Nacional del Sur, B8000CPB Bahía Blanca, Argentina
}

Correspondence should be addressed to Jorge O. Werdin González; jwerdin@hotmail.com

Received 8 November 2013; Accepted 24 December 2013; Published 20 February 2014

Academic Editors: C. Abramson and M. V. Micieli

Copyright (C) 2014 Verónica Benzi et al. This is an open access article distributed under the Creative Commons Attribution License, which permits unrestricted use, distribution, and reproduction in any medium, provided the original work is properly cited.

\begin{abstract}
As part of a screening program to evaluate the biological activity of indigenous plants, we report the composition and the bioactivity of essential oils (EOs) extracted from Té de Burro Aloysia polystachya [(Griseb.) Moldenke] and Lemon Verbena Aloysia citriodora [Palau] against two of the most widespread secondary pests of stored products, the red flour beetle Tribolium castaneum [Herbst] and the confused flour beetle Tribolium confusum [Jacqueline du Val]. Analysis by gas chromatography-mass spectrometry of the EOs led the identification of their major constituents and their relative proportions. EO of $A$. citriodora showed the highest repellent activity against both beetles $(>70 \%)$. On the other hand, both plants showed fumigant toxicity only against T. confusum, without significant differences between them ( $\mathrm{LC}_{50}$ values of 5.92 and $5.53 \mathrm{mg} / \mathrm{L}$ air for A. polystachya and A. citriodora, resp.). For contact toxicity (topical applications) the $\mathrm{EO}$ of $A$. polystachya was more effective $\left(\mathrm{LD}_{50}=7.35 \mu \mathrm{g} / \mathrm{insect}\right)$ than the $\mathrm{EO}$ of $A$. citriodora $\left(\mathrm{LD}_{50}\right.$ $=13.8 \mu \mathrm{g} /$ insect ) only against $T$. castaneum. On the other hand, T. confusum was not susceptible by contact to any of these EOs. These results provide important tools for the development of an Integrated Pest Management (IPM) program.
\end{abstract}

\section{Introduction}

The red flour beetle Tribolium castaneum (Herbst) and the confused flour beetle Tribolium confusum (Duval) (Coleoptera: Tenebrionidae) are the most widespread and destructive secondary pests of stored grains and grain-derived products. They have been reported as serious pests in Argentina. Particularly, T. castaneum has been found as one of the most prevalent secondary pests in port areas of Buenos Aires province [1]. Control of these insects is primarily dependent upon continuous application of synthetic insecticides, which produce disturbance in the environment, increasing costs of application, pest resurgence, pest resistance, and lethal effects on nontarget organisms, in addition to direct toxicity to users. Thus, the risks associated to the use of these products have led to the growth of environmentally sustainable alternatives.

In the last couple of decades, agrochemical companies have promoted the study of natural products for the development of new insecticides. An evidence of that is the number of organic agriculture products that reached the market $[2,3]$. Thus, insecticides of natural origin are proposed as rational alternatives to synthetic ones and, among the biopesticides, essential oils (EOs) are growing rapidly on the botanical pesticide markets [4]. The diversity in their composition and mixture of compounds enhance their insecticide efficacy and reduce the evolution of tolerance and resistance 
to these products. For this purpose, biological activities of diverse plants have been recorded by several authors [5-9]. EOs and their constituents exert insecticidal effects, repel or deter insect food consumption, or reduce and disrupt insect growth. Several species of Verbenaceae have such EOs with biological properties [10-12]. In particular, the genus Aloysia includes approximately 200 species of herbs, shrubs, and small trees. Aloysia polystachya (Griseb.) Moldenke, and Aloysia citriodora (Palau) are native from Argentina and are distributed throughout South and Central America and tropical Africa. The EOs and extracts from these species are valued medicinally, and also their aromatic properties in culinary and cosmetic industries, due to the presence of phenolic compounds (flavonoids) [13]. Moreover, terpenes extracted from these plants have been shown to have important ecological roles in plant defense and attract pollinators, and they have been reported as repellents and insecticides against several pests $[4,14]$.

As part of a screening program to evaluate the bioactivity of native plants as insect control agents, we report the composition, repellent activity, and fumigant and contact toxicity of EOs of A. polystachya and A. citriodora against adults of T. confusum and T. castaneum.

\section{Materials and Methods}

2.1. Insects. T. castaneum and T. confusum are both insecticide-susceptible strains that have been reared in laboratory culture since 1995 and 2005, respectively. Adults of both species were reared in incubators at $28 \pm 1^{\circ} \mathrm{C}$ and $70-80 \%$ R.H. in the dark and fed on a mixture of wheat, yeast, and milk in dust $(13: 1: 1 \mathrm{w}: \mathrm{w} \cdot \mathrm{w})$, in glass containers of $500 \mathrm{~cm}^{3}$.

2.2. Extraction and Analysis of the Composition of Essential Oils. Young fresh leaves from A. polystachya were collected from wild plants, during the summer period at Lamarque city, Rio Negro Province, Argentina ( $39^{\circ} 24^{\prime}$ S. $65^{\circ} 42^{\prime}$ W.). Young fresh leaves from $A$. citriodora were collected from wild plants in Bahía Blanca, Buenos Aires Province, Argentina ( $38^{\circ} 44^{\prime} \mathrm{S}$. $62^{\circ} 16^{\prime} \mathrm{W}$.) Leaves from both plants were collected into plastic bags and kept in the freezer until the extraction. EOs were extracted using a Clevenger-type apparatus by hydro-distillation for $4 \mathrm{~h}$. After the extraction, the EOs were dried using anhydrous sodium sulphate and stored in the dark at $4^{\circ} \mathrm{C}$. Plant oils yields were $0.54 \%\left(\mathrm{mg} \mathrm{g}^{-1}\right)$ for A. polystachya and $0.34 \%\left(\mathrm{mg} \mathrm{g}^{-1}\right)$ for A. citriodora.

The essential oils composition was determined by gas chromatography-mass spectrometry (GC-MS) using a Hewlett-Packard 5890 Series II gas chromatograph, equipped with a HP-5972 (EI-70 eV) mass selective detector and a $25 \mathrm{~m} \times 0.25 \mathrm{~mm}$ i.d., $0.25 \mu \mathrm{m}$ film thickness HP-5MS capillary column with the injection block set $250^{\circ} \mathrm{C}$. The GC oven temperature was held at $50^{\circ} \mathrm{C}$ for $2 \mathrm{~min}$, programmed at $5^{\circ} \mathrm{C}$ $\mathrm{min}^{-1}$ to $200^{\circ} \mathrm{C}$, and then held at this temperature for $10 \mathrm{~min}$. The FID detector temperature was set at $300^{\circ} \mathrm{C}$. The carrier gas was $\mathrm{He}\left(1 \mathrm{~mL} \mathrm{~min}{ }^{-1}\right.$, split ratio 1:50). Aliquots of the essential oils were dissolved in diethyl ether (injection of $2 \mu \mathrm{L}$ ) for the analysis. Oil components were identified by
TABLE 1: Repellency scale from the less to the most repellent $=0$ to $\mathrm{V}$.

\begin{tabular}{lc}
\hline Class & DC $(\%)$ \\
\hline 0 & $<0.1$ \\
I & 0.1 to 20 \\
II & 20.1 to 40 \\
III & 40.1 to 60 \\
IV & 60.1 to 80 \\
V & 80.1 to 100 \\
\hline
\end{tabular}

DC: average distribution coefficient.

TABLe 2: Major identified constituents of Aloysia polystachya and Aloysia citriodora essential oils and their relative proportion in the oils.

\begin{tabular}{lclc}
\hline \multicolumn{1}{c}{ A. citriodora } & \multicolumn{2}{c}{ A. polystachya } \\
Constituents & corr.\% & Constituents & corr.\% \\
\hline Citronellal & 51.29 & Carvone & 83.5 \\
Sabinene & 22.93 & Limonene & 16.5 \\
$\alpha$-curcumene & 9.57 & & \\
Limonene & 7.44 & & \\
Caryophyllene & 2.37 & & \\
$\alpha$-pinene & 2.28 & & \\
$\gamma$-cedrene & 2.27 & & \\
p-cymene & 1.82 & & \\
\hline
\end{tabular}

comparison of their Kobats retention indices with those of known compounds and also by comparison of their mass spectra with those stored in the NBS75K.LMS 86 database.

2.3. Bioassays. All bioassays were set up in laboratory under natural light and controlled temperature and humidity (28 $\pm 1^{\circ} \mathrm{C}$ and $70-80 \%$ R.H). Ten Adults of each species of 35 days old were used for each treatment and control. Five independent replicates were conducted, and all the experimental units were placed at $28 \pm 1^{\circ} \mathrm{C}$ and $70-80 \%$ R.H., in the dark.

2.4. Repellency. Repellency test was conducted according to Talukder and Howse [15]. Filter papers (Whatman $\mathrm{N}^{\circ} 1$, diameter $9 \mathrm{~cm}$ ) were divided into two halves. One half was impregnated with $0.5 \mathrm{~mL}$ of either EO diluted in $n$-hexane (treatment) or $n$-hexane (control). The concentrations evaluated were 90,120 , and $314 \mu \mathrm{g} / \mathrm{cm}^{2}$. Paper disks were air dried, and then placed inside a Petri dish. Ten adult insects were released in the middle of each disk and covered with plastic tape with some holes to prevent insects from escaping. The number of insects on each half of the paper was counted at hourly intervals for $5 \mathrm{~h}$. The distribution coefficient (DC) was calculated using the formula DC $=\left[\left(N_{c}-N_{t}\right) /\left(N_{c}+N_{t}\right)\right] \times 100$, where $N_{c}$ and $N_{t}$ are the number of insects found on the control and treated zone, respectively [16]. The average values were then categorized according to the scale in Table 1.

2.5. Fumigant Toxicity. To determine the fumigant toxicity, filter papers $\left(5 \mathrm{~cm}^{2}\right.$ area) were impregnated with EOs diluted 
TAble 3: Average repellency of EOs of A. polystachya and A. citriodora against T. castaneum and T. confusum.

\begin{tabular}{|c|c|c|c|c|c|c|c|c|c|}
\hline \multirow{3}{*}{ Plant } & \multirow{3}{*}{ Insect } & \multicolumn{7}{|c|}{ Average distribution coefficient (DC\%) ${ }^{1}$} & \multirow{3}{*}{$\mathrm{RC}^{\mathrm{b}}$} \\
\hline & & \multirow{2}{*}{$C^{\mathrm{a}}$} & \multicolumn{5}{|c|}{ Hours after treatment } & \multirow{2}{*}{$\mathrm{MR}^{\mathrm{c}}$} & \\
\hline & & & 1 & 2 & 3 & 4 & 5 & & \\
\hline \multirow{6}{*}{ A. polystachya } & \multirow{3}{*}{ T. castaneum } & 90 & $-13^{\mathrm{a}}$ & $20^{\mathrm{a}}$ & $13^{\mathrm{a}}$ & $40^{\mathrm{a}}$ & $20^{\mathrm{a}}$ & 16 & I \\
\hline & & 120 & $-6^{\mathrm{a}}$ & $-46^{\mathrm{a}}$ & $-60^{\mathrm{a}}$ & $-66^{\mathrm{a}}$ & $-80^{\mathrm{a}}$ & -51.6 & 0 \\
\hline & & 314 & $46^{\mathrm{a}}$ & $33^{\mathrm{a}}$ & $66^{\mathrm{a}}$ & $53^{\mathrm{a}}$ & $46^{\mathrm{a}}$ & 48.8 & III \\
\hline & \multirow{3}{*}{ T. confusum } & 90 & $93^{\mathrm{a}}$ & $86^{\mathrm{a}}$ & $73^{\mathrm{a}}$ & $93^{\mathrm{a}}$ & $93^{\mathrm{a}}$ & 87.6 & $\mathrm{~V}$ \\
\hline & & 120 & $86^{\mathrm{a}}$ & $40^{\mathrm{a}}$ & $40^{\mathrm{a}}$ & $20^{\mathrm{ab}}$ & $33^{\mathrm{a}}$ & 43.8 & III \\
\hline & & 314 & $80^{\mathrm{a}}$ & $60^{\mathrm{a}}$ & $53^{\mathrm{a}}$ & $46^{\mathrm{b}}$ & $46^{\mathrm{b}}$ & 57 & III \\
\hline \multirow{6}{*}{ A. citriodora } & \multirow{3}{*}{ T. castaneum } & 90 & $80^{\mathrm{a}}$ & $93^{\mathrm{a}}$ & $93^{\mathrm{a}}$ & $80^{\mathrm{a}}$ & $100^{\mathrm{a}}$ & 89.2 & $\mathrm{~V}$ \\
\hline & & 120 & $93^{\mathrm{a}}$ & $86^{\mathrm{a}}$ & $73^{\mathrm{a}}$ & $100^{\mathrm{a}}$ & $80^{\mathrm{a}}$ & 74.4 & IV \\
\hline & & 314 & $80^{\mathrm{a}}$ & $80^{\mathrm{a}}$ & $66^{\mathrm{a}}$ & $93^{\mathrm{a}}$ & $93^{\mathrm{a}}$ & 82.4 & $\mathrm{~V}$ \\
\hline & \multirow{3}{*}{ T. confusum } & 90 & $93^{\mathrm{a}}$ & $100^{\mathrm{a}}$ & $100^{\mathrm{a}}$ & $100^{\mathrm{a}}$ & $86^{\mathrm{a}}$ & 95.8 & $\mathrm{~V}$ \\
\hline & & 120 & $80^{\mathrm{a}}$ & $100^{\mathrm{a}}$ & $93^{\mathrm{b}}$ & $100^{\mathrm{a}}$ & $100^{\mathrm{a}}$ & 94.6 & $\mathrm{~V}$ \\
\hline & & 314 & $93^{\mathrm{a}}$ & $86^{\mathrm{a}}$ & $80^{\mathrm{b}}$ & $80^{\mathrm{a}}$ & $67^{\mathrm{a}}$ & 81.2 & $\mathrm{~V}$ \\
\hline
\end{tabular}

${ }^{1} \mathrm{DC} \%=\left[\left(N_{c}-N_{t}\right) /\left(N_{c}+N_{t}\right)\right] \times 100 ;{ }^{\mathrm{a}} \mathrm{C}$ : concentration $\left(\mu \mathrm{g} \mathrm{cm}{ }^{-2}\right) ;{ }^{\mathrm{b}} \mathrm{RC}$ : repellency class; ${ }^{\mathrm{c}} \mathrm{MR}$ : mean rate.

Numbers in the same column of each plant followed by the same letters do not differ significantly in ANOVA test.

TABle 4: Fumigant activity of EOs of A. polystachya and A. citriodora against T. confusum.

\begin{tabular}{lllcrr}
\hline Essential oil & $\mathrm{LC}_{50}{ }^{\mathrm{a}}$ & $95 \% \mathrm{CI}^{\mathrm{c}}$ & $\mathrm{LC}_{95}{ }^{\mathrm{b}}$ & $95 \% \mathrm{CI}^{\mathrm{c}}$ & $\mathrm{Slope}^{2} \mathrm{SE}^{\mathrm{d}}$ \\
\hline A. polystachya & $5.92^{\mathrm{a}}$ & $(5.2-6.5)$ & 11.9 & $(10.08-15.9)$ & $5.37 \pm 0.75$ \\
A. citriodora & $5.53^{\mathrm{a}}$ & $(2.6-6.8)$ & 13.2 & $(10.5-30.6)$ & $4.35 \pm 1.39$ \\
\hline
\end{tabular}

${ }^{\mathrm{a}} \mathrm{LC}_{50}$ : lethal concentration 50 (mg litre ${ }^{-1}$ air); ${ }^{\mathrm{b}} \mathrm{LC}_{95}$ : lethal concentration 95 ( $\mathrm{mg} \mathrm{liter}^{-1}$ air); ${ }^{\mathrm{c}} \mathrm{CI} 95 \%$ : confidence interval of $95 \%$; ${ }^{\mathrm{d}} \mathrm{SE}$ : standard error. Numbers in the same column followed by the same letters do not differ significantly.

in $n$-hexane and controls with $n$-hexane alone. Each filter paper was attached to a glass vial, covered with a fine mesh cloth. These vials were then introduced inside a glass flask of $40 \mathrm{~mL}$. Ten adults of each species were placed inside the flask. Concentrations evaluated were from 1 to $12 \mathrm{mg} / \mathrm{L}_{\text {air }}$. Mortality was evaluated $72 \mathrm{~h}$ after treatment [17].

2.6. Contact Toxicity. For topical applications, aliquots $(0.2 \mu \mathrm{L}$ per insect) were applied ventrally to the thorax of adults using a microapplicator. Controls were determined using $n$-hexane. Both treated and control insects were then transferred to glass vials (10 insects per vial). Ten insects were used for each concentration and control. Concentrations evaluated were from 4 to $18 \mu \mathrm{g} /$ insect. Five independent replicates were conducted. Mortality was registered after $72 \mathrm{~h}$.

2.7. Statistical Analysis. Data from repellency assays (DC) were analyzed using analysis of variance (ANOVA) and minimum significant difference (MSD). Probit analysis was used to estimate $\mathrm{LC}_{50}$ and $\mathrm{DL}_{50}$ values by MicroProbit 3.0. Mortality values were corrected with Abbott's formula [18] to eliminate natural mortality of control.

\section{Results and Discussion}

Analysis by gas chromatography-mass spectrometry of the steam distilled oils showed that the major components of A. polystachya were carvone (83.5\%) and limonene (16.5\%), while A. citriodora was mainly made up of citronellal (51.29\%) and sabinene $(22.93 \%)$ (Table 2 ).

Both EOs had repellent effects against T. castaneum and T. confusum (Table 3 ). However, based on the repellency scale, the activity was stronger with A. citriodora, and it was higher than $70 \%$ to all concentrations evaluated (Table 3 ). The repellent effect of $A$. citriodora is possibly due to the presence of citronellal, which is one of the main constituents $(>50 \%)$ and is a botanical compound use in commercial insect repellents [19]. Similar results were found by OliveroVerbel et al. [20] when tested the repellent effect of Eucalyptus citriodora against $T$. castaneum, which main component is citronellal (40\%). Indeed, the repellent effect of these plants has been also tested against other insects; for instance, Gillij et al. [11] found A. citriodora as one of the most promising EO of the fourteen plants test against Aedes aegypti. Moreover, Gleiser et al. [21] showed a dose-dependent activity of the EO of $A$. polystachya against the same mosquito. Considering that the $\mathrm{EO}$ of $A$. citriodora contains also other compounds such as limonene (7.4\%) with potential repellent effects, synergistic phenomena should not be discarded [22].

For fumigant assay, both EOs were toxic against $T$. confusum but there were no significant differences $(P>0.05)$ between them. However, there were not lethal effects against T. castaneum (Table 4). More studies must be undertaken to elucidate the differences found between the susceptibility of both beetles, but a possible explanation can be based on the differences in the respiration rates of insects. T. castaneum 
TABLE 5: Contact activity of EOs of Aloysia polystachya, and Aloysia citriodora determined by topical application to T. castaneum.

\begin{tabular}{lccccr}
\hline Essential oil & $\mathrm{LD}_{50}{ }^{\mathrm{a}}$ & $95 \% \mathrm{CI}^{\mathrm{c}}$ & $\mathrm{LD}_{95}{ }^{\mathrm{b}}$ & $95 \% \mathrm{CI}^{\mathrm{c}}$ & $\mathrm{Slope}^{\mathrm{a}} \mathrm{SE}^{\mathrm{d}}$ \\
\hline A. polystachya & $7.35^{\mathrm{a}}$ & $(6.38-8.5)$ & 21.95 & $(16.6-34.5)$ & $3.46 \pm 0.47$ \\
A. citriodora & $13.8^{\mathrm{b}}$ & $(9.5-43.7)$ & 124 & $(41-158.2)$ & $1.71 \pm 0.59$ \\
\hline
\end{tabular}

${ }^{\mathrm{a}} \mathrm{LD}_{50}$ : lethal dose $50\left(\mu \mathrm{g}\right.$ insect $\left.{ }^{-1}\right) ;{ }^{\mathrm{b}} \mathrm{LD}_{95}$ : lethal dose $95\left(\mu \mathrm{g}\right.$ insect $\left.{ }^{-1}\right) ;{ }^{\mathrm{c}} \mathrm{CI} 95 \%$ : confidence interval of $95 \%$; ${ }^{\mathrm{d}} \mathrm{SE}$ : standard error. Numbers in the same column followed by the same letters do not differ significantly.

has a lower rate of air exchange and consequently a smaller diffusion of toxic compounds into the insect [23, 24].

For contact toxicity, no lethal effects were found against adults of T. confusum. However, significant differences were found between EOs, against T. castaneum $(P<0.05)$. A. polystachya showed the highest toxicity (Table 5). Carvone, the main compound of A. polystachya, has been found to be toxic against diverse insects, for example, Fang et al. [25] found strong contact toxicity of carvone and limonene, against Sitophilus zeamais and T. castaneum. Moreover, carvone caused the highest mortality against larvae of $T$. castaneum among the several monoterpenes evaluated $\left(\mathrm{LC}_{50}=\right.$ $19.8 \mu \mathrm{g} / \mathrm{cm}^{2}$ ) [26]. On the other hand, the concentration of these products has been found as an important factor that determines their toxicity, and it is directly proportional to the rate of penetration of a substance [27-29]. Carvone found in A. polystachya is denser than citronellal found in A. citriodora, thus this can be related with the differences found in the contact activity of both EOs. Similar results were found earlier with the EOs of A. polystachya against $R$. dominica (Fabricius) and Nezara viridula (L.) $[12,30]$.

\section{Conclusions}

This is the first report on the repellent and insecticidal activities of EOs of A. citriodora and A. polystachya (Verbenaceae) against $T$. castaneum and T. confusum, two of the most widespread secondary pests in the world. The results present herein indicate that EOs extracted from these indigenous plants showed repellent and bioinsecticides properties. The $\mathrm{EO}$ of A. polystachya had the greatest contact toxicity against T. castaneum. Both EOs had the same fumigant activity against T. confusum.

In summary, these EOs are good options for the control of stored grain pests but they need to be studied under commercial storage conditions.

\section{Conflict of Interests}

The authors declare that there is no conflict of interests regarding the publication of this paper.

\section{Acknowledgment}

Financial assistance was provided by SECYT-UNS CONICET.

\section{References}

[1] L. R. Descamps, N. Stefanazzi, C. Sanchez Chopa, and A. A. Ferrero, "Actividad biológica de extractos vegetales de Schinus molle var. areira (Anacardiaceae) en Tribolium castaneum Herbst. (Insecta, Coleoptera, Tenebrionidae), plaga de grano almacenado," Boletín de la Sanidad Vegetal-Plagas, vol. 34, pp. 595-605, 2008.

[2] C. L. Cantrell, F. E. Dayan, and S. O. Duke, "Natural products as sources for new pesticides," Journal of Natural Products, vol. 75, pp. 1231-1242, 2012.

[3] C. Regnault-Roger, C. Vincent, and J. T. Arnason, "Essential oils in insect control: low-risk products in a high-stakes world," Annual Review of Entomology, vol. 57, pp. 405-424, 2012.

[4] S. Zoubiri and A. Baaliouamer, "Chemical composition and insecticidal properties of some aromatic herbs essential oils from Algeria," Food Chemistry, vol. 129, no. 1, pp. 179-182, 2011.

[5] M. B. Isman, C. M. Machial, S. Miresmailli, and L. D. Bainard, "Essential oil-based pesticides: new insights from old chemistry," in Pesticide Chemistry-Crop Protection, Public Health, Environmental Healthy, H. Ohkawa, H. Miyagawa, and P. W. Lee, Eds., Wiley-VCH, Weinheim, Germany, 2007.

[6] D. W. Onstad, Insect Resistance Managment: Biology, Economics and Prediction, Elsevier, London, UK, 2008.

[7] H. F. Khater, "Prospects of botanical biopesticides in insect pest management," Journal of Applied Pharmaceutical Science, vol. 2, no. 5, pp. 244-259, 2012.

[8] N. Stefanazzi, T. Stadler, and A. Ferrero, "Composition and toxic, repellent and feeding deterrent activity of essential oils against the stored-grain pests Tribolium castaneum (Coleoptera: Tenebrionidae) and Sitophilus oryzae (Coleoptera: Curculionidae)," Pest Management Science, vol. 67, no. 6, pp. 639-646, 2011.

[9] S. B. Padín, C. Fusé, M. Urrutia, and G. dal Bello, "Toxicity and repellency of nine medicinal plants against Tribolium castaneum in stored wheat," Bulletin of Insectology, vol. 66, no. 1, pp. 45-49, 2013.

[10] R. M. Gleiser and J. A. Zygadlo, "Insecticidal properties of essential oils from Lippia turbinata and Lippia polystachya (Verbenaceae) against Culex quinquefasciatus (Diptera: Culicidae)," Parasitology Research, vol. 101, no. 5, pp. 1349-1354, 2007.

[11] Y. G. Gillij, R. M. Gleiser, and J. A. Zygadlo, "Mosquito repellent activity of essential oils of aromatic plants growing in Argentina," Bioresource Technology, vol. 99, no. 7, pp. 2507-2515, 2008.

[12] J. O. Werdin González, M. M. Gutiérrez, A. P. Murray, and A. A. Ferrero, "Biological activity of essential oils from Aloysia polystachya and Aloysia citriodora (verbenaceae) against the soybean pest Nezara viridula (hemiptera: pentatomidae)," Natural Product Communications, vol. 5, no. 2, pp. 301-306, 2010. 
[13] S. R. Fuselli, S. B. G. de la Rosa, M. J. Eguaras, and R. Fritz, "Susceptibility of the honeybee bacterial pathogen Paenibacillus larvae to essential oils distilled from exotic and indigenous Argentinean plants," Journal of Essential Oil Research, vol. 20, no. 5, pp. 464-470, 2008.

[14] J. M. Kembro, R. H. Marin, J. A. Zygadlo, and R. M. Gleiser, "Effects of the essential oils of Lippia turbinata and Lippia polystachya (Verbenaceae) on the temporal pattern of locomotion of the mosquito Culex quinquefasciatus (Diptera: Culicidae) larvae," Parasitology Research, vol. 104, no. 5, pp. 1119-1127, 2009.

[15] F. A. Talukder and P. E. Howse, "Deterrent and insecticidal effects of extracts of pithraj, Aphanamixis polystachya (Meliaceae), against Tribolium castaneum in storage," Journal of Chemical Ecology, vol. 19, no. 11, pp. 2463-2471, 1993.

[16] A. L. Tapondjou, C. Adler, D. A. Fontem, H. Bouda, and C. Reichmuth, "Bioactivities of cymol and essential oils of Cupressus sempervirens and Eucalyptus saligna against Sitophilus zeamais Motschulsky and Tribolium confusum du Val," Journal of Stored Products Research, vol. 41, no. 1, pp. 91-102, 2005.

[17] M. -J. Pascual Villalobos, M. C. Ballesta Acosta, and A. Soler, "Toxicidad y repelencia de aceites esenciales en plagas de almacén de arroz," Boletín de la Sanidad Vegetal-Plagas, vol. 30, pp. 279-286, 2004

[18] W. S. Abbot, "A method of computing the effectiveness of an insecticide," Journal of Economic Entomology, vol. 18, pp. 265267, 1925.

[19] T. G. Jaenson, K. Pålsson, and A. K. Borg-Karlson, "Evaluation of extracts and oils of mosquito (Diptera: Culicidae) repellent plants from Sweden and Guinea-Bissau," Journal of Medical Entomology, vol. 43, no. 1, pp. 113-119, 2006.

[20] J. Olivero-Verbel, L. S. Nerio, and E. E. Stashenko, "Bioactivity against Tribolium castaneum Herbst (Coleoptera: Tenebrionidae) of Cymbopogon citratus and Eucalyptus citriodora essential oils grown in Colombia," Pest Management Science, vol. 66, no. 6, pp. 664-668, 2010.

[21] R. M. Gleiser, M. A. Bonino, and J. A. Zygadlo, "Repellence of essential oils of aromatic plants growing in Argentina against Aedes aegypti (Diptera: Culicidae)," Parasitology Research, vol. 108, no. 1, pp. 69-78, 2011.

[22] C. Yoon, S. H. Kang, J. O. Yang, D. J. Noh, P. Indiragandhi, and G. H. Kim, "Repellent activity of citrus oils against the cockroaches Blattella germanica, Periplaneta americana and $P$. fuliginosa," Journal of Pesticide Science, vol. 34, no. 2, pp. 77-88, 2009.

[23] M. Emekci, S. Navarro, E. Donahaye, M. Rindner, and A. Azrieli, "Respiration of Tribolium castaneum (Herbst) at reduced oxygen concentrations," Journal of Stored Products Research, vol. 38, no. 5, pp. 413-425, 2002.

[24] D. C. Stamopoulos, P. Damos, and G. Karagianidou, "Bioactivity of five monoterpenoid vapours to Tribolium confusum (du Val) (Coleoptera: Tenebrionidae)," Journal of Stored Products Research, vol. 43, no. 4, pp. 571-577, 2007.

[25] R. Fang, C. H. Jiang, X. Y. Wang et al., "Insecticidal activity of essential oil of Carum Carvi fruits from china and its main components against two grain storage insects," Molecules, vol. 15, no. 12, pp. 9391-9402, 2010.

[26] S. A. M. Abdelgaleil, M. I. E. Mohamed, M. E. I. Badawy, and S. A. A. El-Arami, "Fumigant and contact toxicities of monoterpenes to Sitophilus oryzae (L.) and Tribolium castaneum (Herbst) and their inhibitory effects on acetylcholinesterase activity," Journal of Chemical Ecology, vol. 35, no. 5, pp. 518-525, 2009.

[27] P. M. Dewick, "The biosynthesis of C5-C25 terpenoid compounds," Natural Product Reports, vol. 19, no. 2, pp. 181-222, 2002.

[28] V. Rozman, I. Kalinovic, and Z. Korunic, "Toxicity of naturally occurring compounds of Lamiaceae and Lauraceae to three stored-product insects," Journal of Stored Products Research, vol. 43, no. 4, pp. 349-355, 2007.

[29] A. K. Phillips, Toxicity and Repellency of Essential Oils to the German Cockroach (Blatella Germanica), Auburn University, Auburn, Ala, USA, 2009.

[30] V. S. Benzi, A. P. Murray, and A. A. Ferrero, "Insecticidal and insect-repellent activities of essential oils from verbenaceae and anacardiaceae against Rhizopertha dominica," Natural Product Communications, vol. 4, no. 9, pp. 1287-1290, 2009. 

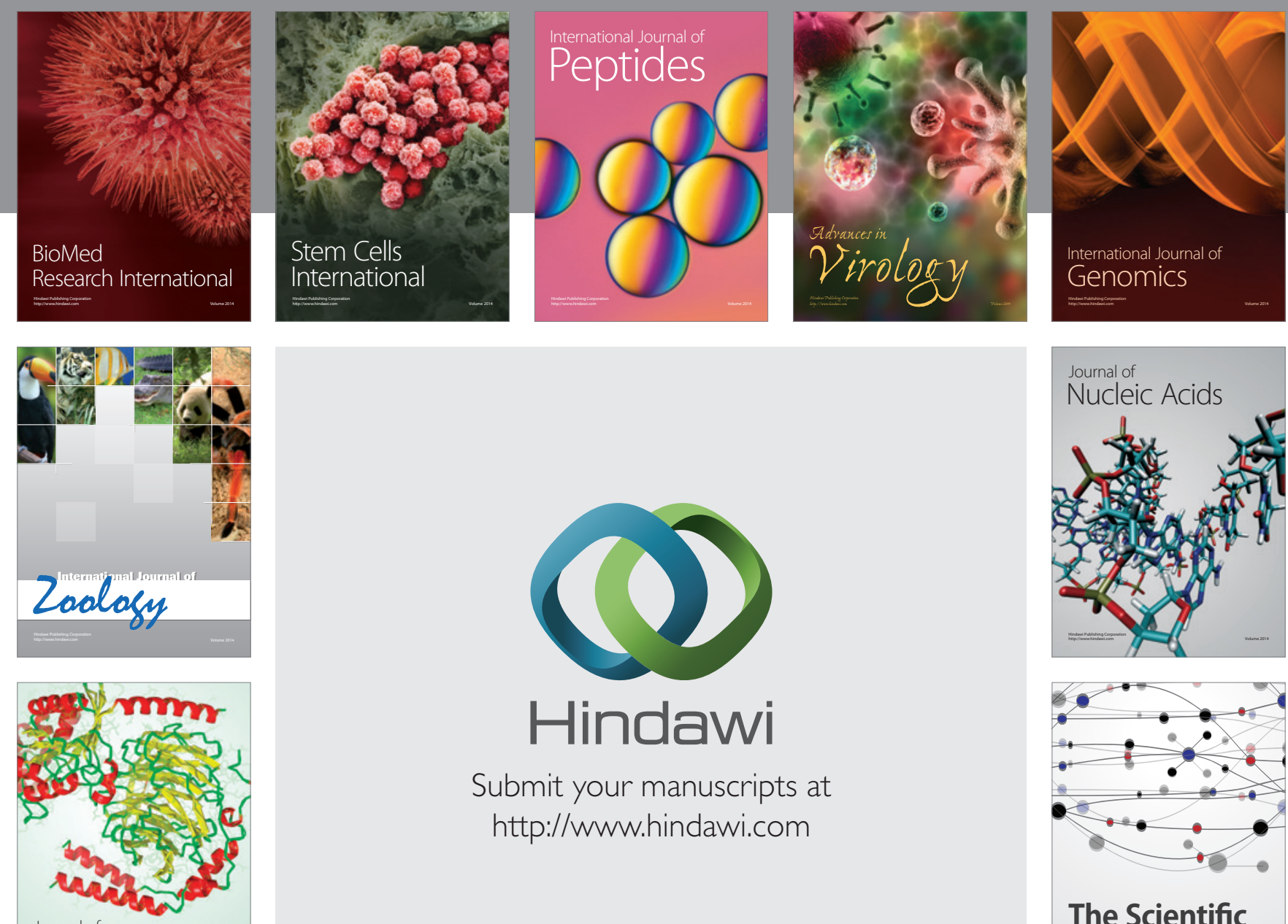

Submit your manuscripts at

http://www.hindawi.com

Journal of
Signal Transduction
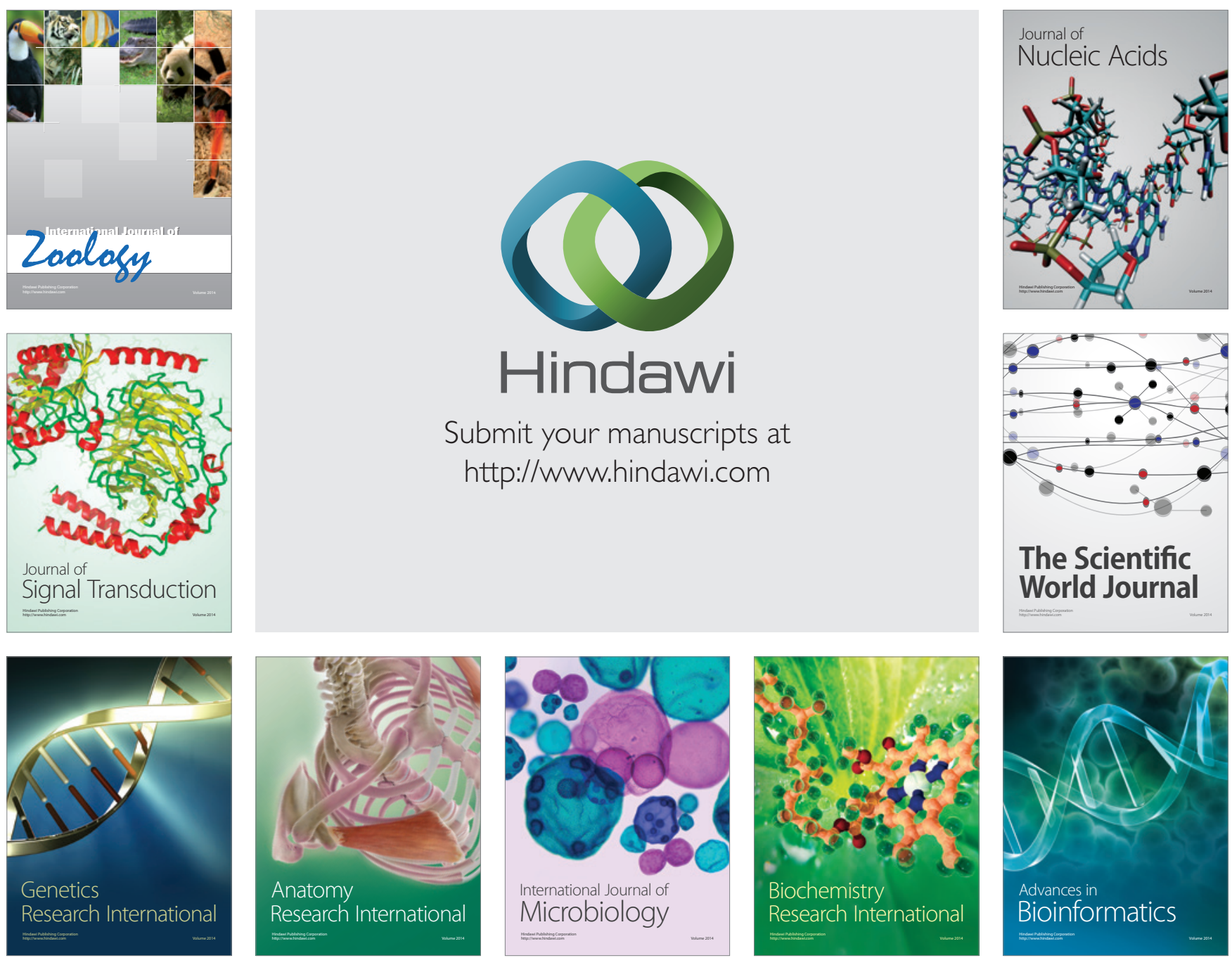

The Scientific World Journal
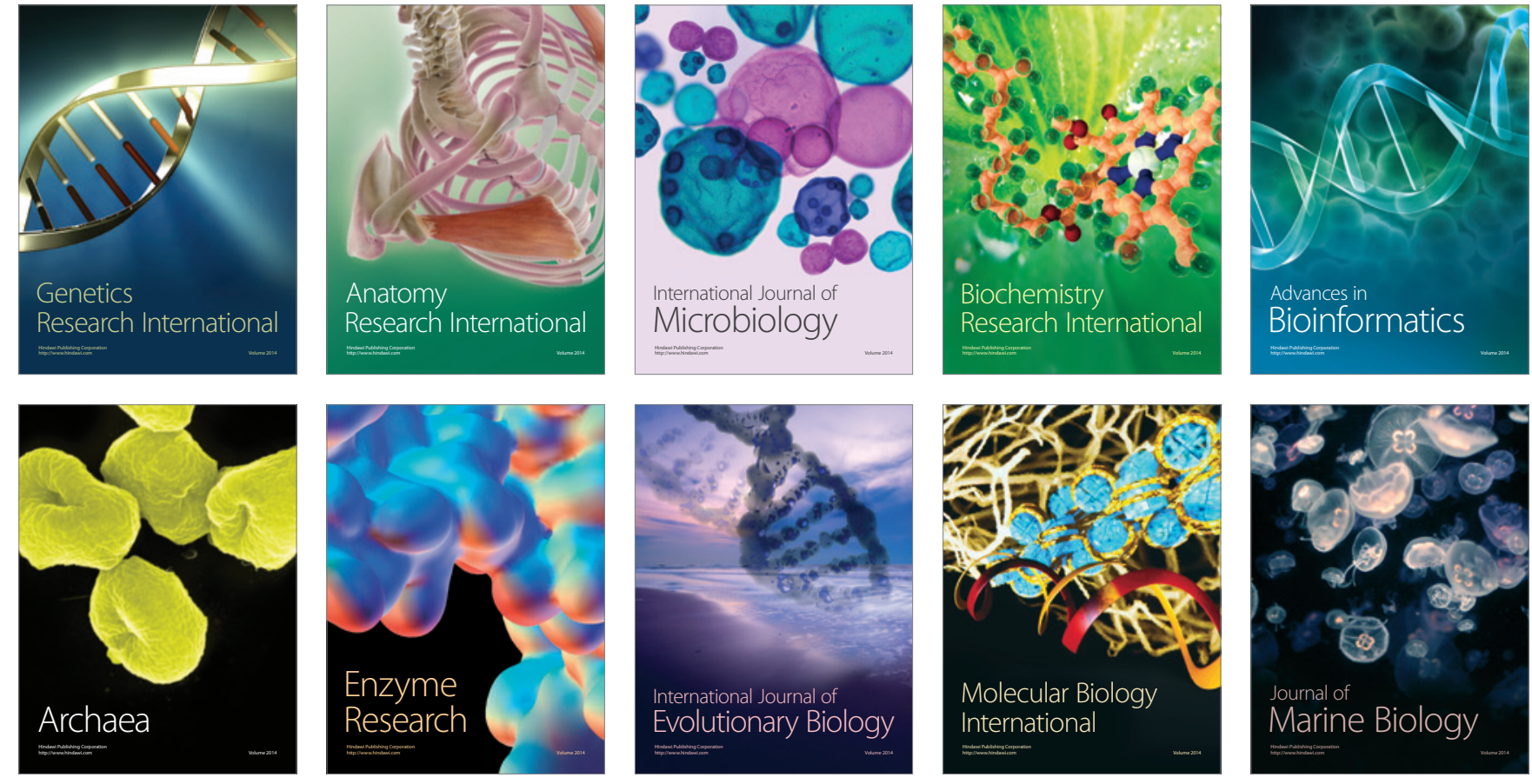